Отримано:12 листопада 2018 р.

Прорецензовано: 13 листопада 2018 р.

Прийнято до друку: 14 листопада 2018 р.

e-mail: anyavarina22@gmail.com

DOI: $10.25264 / 2415-7384-2018-7-19-23$
Каткова Т. А., С. В. Мельнікова, Варіна Г. Б. Агресивні прояви підлітків як чинник виникнення конфліктних ситуацій у родині. Наукові записки Національного університету «Острозька академія». Серія «Психологія» : збірник наукових праџь. Острог : Вид-во НаУОА, листопад 2018. № 7. С. 19-23.

\begin{abstract}
Каткова Тетяна Анатоліївна,
магістр психології, старший викладач кафедри психологї

Мелітопольського державного педагогічного університету імені Богдана Хмельницького

Мельнікова Світлана Вадимівна,

кандидат медичних наук, доиент кафедри психології

Мелітопольського державного педагогічного університету імені Богдана Хмельницького

Варіна Ганна Борисівна,

магістр психологї̈, старший викладач кафедри психологї

Мелітопольського державного педагогічного університету імені Богдана Хмельницького

УДК 159.922

\section{АГРЕСИВНІ ПРОЯВИ ПІДЛІТКІВ ЯК ЧИННИК ВИНИКНЕННЯ КОНФЛІКТНИХ СИТУАЦІЙ У РОДИНІ}

Стаття присвячена вивченню проблеми впливу агресивної поведінки в підлітковому віці на виникнення конфліктних ситуачій у родині. Теоретично доведена необхідність дослідження особливостей впливу агресивних проявів дітей підліткового віку на відносини з батьками у позитивному спрямуванні. Розроблена корекційна програма розрахована на допомогу підліткам в формуванні конструктивних патернів поведінки в процесі подолання агресивних проявів у взаєминах з батьками. Під час дослідження використані теоретичні (обробка наукових та періодичних видань з теми дослідження, порівняння); емпіричні методи дослідження; кількісні та якісні методи обробки даних. Після проведення експериментального дослідження ми дійшли такого висновку, що рівень агресивності учнів завищений, і тому можуть виникати конфліктні ситуації у спілкуванні з дорослими та однолітками. У статті окреслено шляхи майбутнього вивчення проблеми дослідження.
\end{abstract}

Ключові слова: агресія, агресивність, конфлікт, міжособистісні відносини, підлітки.

Tetiana Katkova,

Master of Psychology, Senior Lecturer of the Department of Psychology,

Melitopol State Pedagogical University named after Bohdan Khmelnytskyi

Svitlana Melnikova,

Candidate of Medical Sciences, Associate Professor of the Department of Psychology

Melitopol State Pedagogical University named after Bohdan Khmelnytskyi

Anna Varina,

Master of Psychology, Senior Lecturer of the Department of Psychology,

Melitopol State Pedagogical University named after Bohdan Khmelnytskyi

\title{
AGGRESSIVE MANIFESTATIONS OF ADOLESCENTS AS A FACTOR OF THE EMERGENCE OF CONFLICT SITUATIONS IN FAMILY
}

The article is devoted to the study of the impact of aggressive behavior in adolescence on the emergence of conflict situations in family. The necessity of studying the peculiarities of the influence of aggressive manifestations of adolescent children on relationships with parents in a positive direction was theoretically proved. The developed correction program is designed to help teenagers in the formation of constructive patterns of behavior in the process of overcoming aggressive manifestations in relationships with parents. During the research there were used theoretical (processing of scientific and periodicals on the subject of research, comparison); empirical research methods; quantitative and qualitative data processing methods. After conducting the experimental study, we came to the conclusion that the level of student aggression is overestimated and that conflict situations can arise in communicating with adults and peers. The article outlines the ways of further studying the research problem.

Key words: aggression, conflict, interpersonal relations, adolescents.

Постановка проблеми. Проблема агресивності - одна 3 найзначущих проблем не тільки для сучасної психології й педагогіки, але й суспільства в цілому. Актуальність дослідження полягає у тому, що саме в підлітковому віці не тільки відбувається корінна перебудова раніше сформованих психологічних структур, але виникають нові утворення, закладаються основи свідомої поведінки, вимальовується загальна спрямованість у формуванні моральних норм і соціальних настанов. Сьогодні наше суспільство характеризують серйозним дефіцитом позитивного впливу на підлітків. Відбувається «деформація» родини, яка не виконує важливі функції, як-от формування у дітей почуття психологічного комфорту та за- 
хищеності. У результаті для багатьох підлітків характерна нерозвиненість моральних установ, споживча орієнтація, емоційна брутальність, агресивний спосіб самоствердження. Наявність надзвичайно високої концентрації агресії в суспільстві й відсутність однозначного й адекватного наукового визначення цього складного феномена роблять проблему дослідження агресивності у підлітковому віці, що $є$ основою для виникнення конфліктів у родині, однієї з найбільш актуальних проблем сучасного світу, важливим теоретичним і практичним завданням. Психологи-дослідники дедалі більше приділяють увагу вивченню самого феномену агресії, агресивним проявам і тенденціям поведінки, питанням профілактики агресивності. Кожен автор по-різному визначає агресію та агресивність: як вроджену реакцію людини для «захисту зайнятої території» (К. Лоренц, М. Ардри); реакція особистості на ворожу людиною навколишню дійсність (К. Хорні, Е. Фром), дуже поширені теорії, що пов'язують агресію та фрустрацію (Дж. Доллард, Л. Берковітц).

Однак, неможна розглядати агресивність тільки як негативне явище. Треба пам'ятати про те, що вона може закономірно виростати на фоні підвищеної активності підлітка в процесі його ефективного розвитку.

Короткий огляд останніх досліджень і публікацій. Існує кілька різноспрямованих теоретичних перспектив, кожна з яких дає своє бачення сутності та витоків агресії. Найстаріша 3 них - теорія інстинкту, яка розглядає агресивну поведінку як вроджене. 3. Фрейд, найзнаменитіший з прихильників цієї досить поширеної точки зору, вважав, що «агресія бере свій початок у природженому і спрямованому на власного носія інстинкті смерті; по суті справи, агресія - це той же інстинкт, тільки спроектований удвічі і націлений на зовнішні об'єкти» [10].

Одна з найбільш цікавих наслідків теорії К. Лоренца полягає в тому, що з ії допомогою можна пояснити той факт, що у людей, на відміну від більшості інших живих істот, найбільше поширене насильство по відношенню до представників свого власного виду. К. Лоренц також стверджував, що любов і дружні відносини можуть виявитися несумісними з вираженням відкритої агресії і можуть блокувати іiї прояв [4].

В психології існують різні підходи, що пояснюють природу походження агресивності як властивості особистості. Підліткове «почуття дорослості» головним чином новий рівень претензій та захоплюючого положення. Для підлітка дуже важливо, щоб його дорослість була помітна оточуючими, щоб форма його поведінки не була дитячою. Цінність діяльності для підлітка визначаємо ії дорослістю, представлення про норми поведінки, що вже виникло раніше, дає можливість обговорювати поведінку дорослих, через це виникають вікові конфлікти [7]. Проекція сімейних взаємовідносин і настановлень служить підлітку орієнтиром в повсякденному житті і міжособистісних контактах. Можна припустити, що в сім'ях, де підліток обділений увагою дорослих, де немає довірливих взаємовідносин, формується почуття ворожості до всього навколишнього світу. Агресивна поведінка підлітків - проблема, яка хвилює батьків і вчителів. Дослідники стверджують, що агресивні і неагресивні підлітки мають різний ступінь прихильності до батьків і близькості з ними. Предметом одного такого дослідження було вивчення особливостей ідентифікації з батьками агресивних і неагресивних підлітків. Загалом було встановлено, що у неагресивних підлітків ідентифікація з власними батьками виражена сильніше, ніж у агресивних. Однак ступінь відмінності між цими двома групами підлітків з ідентифікації з матір'ю і батьком виявився неоднаковим. Найбільш сильні відмінності між агресивними і неагресивними підлітками виявляються за ступенем ідентифікації з батьком. Відповідні відмінності за ступенем ідентифікації з матір'ю виявилися менш вираженими. Тобто ідентифікація з матір'ю як у неагресивних, так і в агресивних підлітків виявилася високою і досить близькою за середньогруповим показником [6].

Останній факт, на нашу думку, можна інтерпретувати як прояв особливого значення матері в системі уподобань і соціальних відносин підлітка. Очевидно, порушення ідентифікації з матір'ю можуть бути виявлені не за будь-яких, а тільки за дуже серйозних порушень розвитку особистості. Загалом, як встановлено в дослідженні, негативне ставлення до матері - важливий показник загального неблагополучного розвитку особистості.

Усередині підліткового віку як у хлопчиків, так і у дівчаток існують вікові періоди з більш високим і більш низьким рівнем прояву агресивної поведінки. Також встановлено, що у хлопчиків $є$ два піки прояву агресії: 12 років і 14-15 років. У дівчаток теж виявляються два піки: найбільший рівень прояву агресивної поведінки відзначається в 11 років і 13 років.

У дослідженнях психологів було показано, що якщо у 10-11-річних підлітків переважають прояви фізичної агресії, то в міру дорослішання у підлітків 14-15 років на перший план виходить вербальна агресія. Однак це не пов’язано зі зниженням прояву фізичної агресії з віком. Максимальні показники прояву всіх форм агресії виявляються саме в 14-15 років. Але динаміка зростання фізичної і вербальної агресії в міру дорослішання неоднакова: прояви фізичної агресії хоча і збільшуються, але незначно [9].

У дослідженні А. А. Реан було показано, що рівень фізичної агресії підлітків 14-16 років корелює 3 рівнем загальної самооцінки особистості. Чим вищою була самооцінка, тим більше була виражена i 
схильність до прояву фізичної агресії. Конфлікти - невід’ємна частина людських взаємовідносин, і неможна говорити про те, що вони безкорисні або патологічні. Конфлікти виникають через відмінності між людьми, тому що вчинки, уявлення, почуття в кожного з нас різні. У кожної людини є свої позитивні і негативні якості [5].

Міжособистісні відносини здійснюються в умовах конфліктів, які є невід’ємною частиною людських відносин. Конфлікт - найбільш гострий спосіб усунення протиріч, що виникають у процесі взаємодії, що полягають в протидії суб'єктів конфлікту і, звичайно, супроводжуються негативними емоціями. Досить специфічними є відносини батьків $з$ дітьми, які не досягли повноліття. Такі конфлікти - найпоширеніші в сімейному житті, оскільки одна з головних особливостей підліткового віку - зміна соціальних ролей, перебудова взаємовідносин з дорослими [8].

Психологи, починаючи з Л. С. Виготського, одностайно вважають головним новоутворенням підліткового віку - почуття дорослості. Однак орієнтація на дорослі цінності і порівняння себе 3 дорослими найчастіше змушують підлітка знову бачити себе відносно маленьким й несамостійним. За такої умови, на відміну від дитини, він вже не вважає таке положення нормальним і прагне його перебороти. Звідси суперечливість почуття дорослості: підліток претендує бути дорослим і в той же час знає, що рівень його домагань далеко не в усьому підтверджений і виправданий. Одна з найважливіших потреб підліткового віку - потреба у звільненні від контролю й опіки батьків та вчителів, а також від встановлених ними правил і порядків.

3 факторів соціалізації найважливішою, найвпливовішою була і залишається сім'я як первинний осередок суспільства, вплив якого дитина випробує насамперед. Крім свідомого, цілеспрямованого виховання, що дають йому батьки, на дитину впливає внутрішньо сімейна атмосфера, при чому ефект цього впливу накопичується з віком, і стає переломним. Соціальний та психологічний аспект поводження підлітків залежить від сімейних умов, які визначають життєвий шлях дитини. Крім освітнього рівня батьків, сильно впливає на долю підлітків склад родини і характер взаємин між їі членами. Несприятливі сімейні умови характерні для більшості, так званих «важких підлітків». Існують автономні психологічні механізми, за допомогою яких батьки впливають на своїх дітей: підкріплення, ідентифікація, розуміння. Знаючи внутрішній світ дитини і чуйно відгукуючись на його проблеми, батьки тим самим формують його самосвідомість і комунікативні якості. Існує інший бік взаємовідносин батьків і дітей, який включає в себе фактори, що є причинами конфліктної взаємодії дорослих та підлітків. До них належать: типи сімейних відносин, стилі виховання, сімейний тон спілкування, неефективність батьківського відношення до дитини, особистісні відмінності батьків і дітей.

У сімейних відносинах виділяють гармонійний і дисгармонійні типи. Для гармонійних відносин характерне співробітництво, взаємодопомога, рівноправність всіх учасників сім’ї. Для такої сім’ї характерний демократичний стиль виховання дитини, такі батьківські дії дають ефект розуміння, прийняття і розуміння особистості дитини. У дисгармонійній сім’ї спостерігаємо конфліктну взаємодію подружжя, напруженість, неможливість віднайти гідного способу спілкування між батьками і дітьми, нехтування почуттями та емоціями сторін, збереження у взаємовідносинах дистанції. Відсутність стабільних цінностей і норм поведінки в такій сім’ї призводить до погіршення здоров'я дітей.

Учені виокремлюють типи неправильного батьківського виховання, які спричиняють дисгармонійне формування особистості дитини: неприйняття, емоційне відторгнення (до дитини ставляться зневажливо, принижують, ображають ㄲi, навіть нехтують); гіпоопіка (батьки недостатньо турбуються про дитину, не звертають на неї уваги, не контролюють, нерідко вона потрапляє під негативні впливи); гіперопіка (дитина позбавлена будь-якої форми самостійності, жорсткий контроль за кожним кроком дитини). Тиранічна, некритична любов батьків спотворює душі таких дітей. Різні способи батьківського контролю також можна презентувати у виді шкали, на одному полюсі якої висока активність, самостійність і ініціатива дитини, а на іншому - пасивність, залежність, сліпу слухняність. Найкращі взаємини старшокласників з батьками створюються тоді, коли батьки дотримуються демократичного стилю виховання. Цей стиль найбільшою мірою сприяє вихованню самостійності, активності, ініціативи і соціальної відповідальності. Поведінку дитини направляють у цьому випадку послідовно і разом з тим гнучко і раціонально.

У нашій країні існують різні стилі сімейного виховання, що багато в чому залежать як від національних традицій, так і від індивідуальних особливостей. Подорослішавши, люди часто відтворюють те, що 3 ними самими проробляли батьки, навіть якщо вони пам'ятають, як важко їм доводилося. Характер сімейного виховання дуже тісно пов'язаний зі стилем суспільних відносин узагалі. Люди несвідомо зганяють на дітях свої службові невдачі, роздратування, що виникає в чергах, переповненому транспорті. Низький рівень педагогічної культури, переконаність у тому, що кращий спосіб дозволу будь-яких конфліктних ситуацій - сила.

Через незнання особливостей підліткового віку виникають непорозуміння між дорослими та дітьми. Як правило, дитина на домагання і конфліктні дії батьків відповідає такими реакціями: опозиції (демон-

Наукові записки Національного університету «Острозька академія», серія «Психологія», № 7, листопад, 2018 р. 
стративні дії негативного характеру); відмови (непокора вимогам батьків); ізоляції (прагнення уникнути небажаних контактів з батьками, приховування інформації та дій) [2].

Найбільше підлітки бажають бачити в батьках друзів і порадників. При всьому прагненні до самостійності юнаки і дівчата мають гостру потребу в життєвому досвіді та допомозі старших. Багато проблем, що їх турбують, вони взагалі не можуть обговорювати з однолітками, тому що заважає їм самолюбство. Родина залишається тим місцем, де підліток почуває себе найспокійніше і найвпевненіше. Однак взаємини підлітків з батьками часто обтяжені конфліктами та їхнє взаєморозуміння залишає бажати кращого. Тому в пошуках власної ідентичності підліток може кидати виклики сімейним правилам, регламентуючи особисте життя, шокувати сім'ю нетиповими для неї цінностями і поведінкою. Це нерідко приводить до росту конфліктності в сім'ї, основними аспектами яких є: акуратність, допомога в домашньому господарстві, успішність в школі, спілкування з однолітками, зовнішній вигляд підлітка, шкідливі звички, еротика і секс [3].

До несприятливих рис батьків належать: холодність, вимогливість, консерватизм, надмірний раціоналізм, недостатність ніжності, підвищена тривожність та шкідливі звички. Серед особистісних особливостей дітей називають: низьку успішність, порушення правил поведінки, ігнорування рекомендацій батьків, непослух, впертість, егоцентризм та самовпевненість.

Виховуючи дитину, слід враховувати особливості свого характеру. Критичне ставлення до своєї поведінки нерідко допомагає змінити іiі. Таким чином, розглянуті конфлікти можуть бути представлені як результат помилок батьків і дітей. Труднощі виконання сім'єю виховної функції значною мірою пов'язані із знеціненням моральних, духовних, громадянських ідеалів у суспільстві, відсутністю спільних стратегій виховання дітей у сім'ї, недостатньою підготовкою молоді до материнства та батьківства. Низький рівень педагогічної культури батьків послаблює можливості передачі досвіду від старших поколінь молодшим, збіднює сімейне спілкування, зменшує батьківський вплив на дітей. Отже, причини неблагополуччя полягають в особистому досвіді кожного члена сім'ї [1].

Мета статті: вивчити вплив агресивної поведінки в підлітковому віці на виникнення конфліктних ситуацій у родині. На виконання поставленої мети були виокремлені такі завдання: провести теоретичний аналіз одного з найважливіших періодів розвитку людини підліткового віку; визначити рівень впливу сімейного середовища на становлення підліткової агресії; встановити роль та особливості агресивної поведінки підлітків; провести експериментальне дослідження особливостей впливу агресивних проявів дітей підліткового віку на відносини з батьками у позитивному спрямуванні; запропонувати методи профілактики й корекції агресивної поведінки підлітків.

Матеріали і методи дослідження. Для вирішення поставлених завдань та реалізації мети дослідження було використано комплекс взаємопов'язаних методів. На виконання першого завдання було опрацьовувано та проаналізовано науково-методичну літературу. На виконання другого завдання - порівняння, узагальнення, систематизація наукової літератури. На виконання третього завдання було використано індуктивний аналіз.

Виклад основного матеріалу. Експериментальною базою нашого дослідження було обрано гімназію № 19 м. Мелітополь. Щоб зробити певний порівняльний аналіз, ми провели підібрані методики на 34 учнях підліткового віку. Потім розділили клас на дві підгрупи: експериментальну і контрольну по 17 учнів у кожній. Для вивчення проблеми дослідження стану агресії в підлітків нами було проведено методику «Діагностика стану агресії у підлітків». Порівнявши результати, отримані до проведення корекційної роботи і після, спостерігаємо, що нормальний рівень агресивності у контрольній підгрупі підвищився на $2 \%$, а високий - знизився на $2 \%$; в експериментальній підгрупі високий рівень знизився на $6 \%$, а нормальний - підвищився на $6 \%$.

Після проведення методики «Діагностика самооцінки психічних станів особистості» та обробки отриманих даних можна робити певні висновки щодо наявності агресивності у дітей підліткового віку. Порівнявши результати, отримані до проведення корекційної роботи (тренінгові заняття) і після, спостерігаємо, що нормальний рівень агресивності у контрольній підгрупі знизився на $3 \%$, а високий - підвищився на $3 \%$; в експериментальній підгрупі нормальний рівень підвищився на $2 \%$, а високий - знизився на $3 \%$.

Метод незакінчених речень допоміг визначити систему відношень дитини до батька, матері, сім’ї в цілому та до самої себе. Порівнявши результати, отримані до проведення корекційної роботи і після, спостерігаємо певні зміни. Ставлення до батька в експериментальній підгрупі «позитивний» рівень підвищився на $32 \%$, «байдужий» - знизився на $10 \%$, «негативний»- знизився на $22 \%$. Ставлення до батька в контрольній підгрупі «позитивний» рівень підвищився на $19 \%$, «байдужий» - знизився на $2 \%$, «негативний» - знизився на $16 \%$. Ставлення до матері в експериментальній підгрупі «позитивний» рівень підвищився на $2 \%$, «байдужий» - підвищився на $6 \%$, «негативний» - знизився на $8 \%$. Ставлення до матері в контрольній підгрупі «позитивний» рівень залишився незмінним, «байдужий» - підвищився на $6 \%$, «негативний»- знизився на $6 \%$. Ставлення до сім'ї загалом в експериментальній підгрупі «позитивний» 
рівень підвищився на $8 \%$, «байдужий» - знизився на $1 \%$, «негативний» - знизився на $7 \%$. Ставлення до сім’ї в контрольній підгрупи «позитивний» рівень підвищився на $3 \%$, «байдужий» - підвищився на $2 \%$, «негативний» - знизився на 5\%. Ставлення до самого себе в експериментальній підгрупі «позитивний» рівень підвищився на $19 \%$, «байдужий» - знизився на 7\%, «негативний» - знизився на $12 \%$. Ставлення до самого себе в контрольній підгрупи «позитивний» рівень підвищився на $2 \%$, «байдужий» - підвищився на $5 \%$, «негативний» - знизився на 7\%. Для точності дослідження ми запропонували учням проективну методику «Кінетичний малюнок сім'ї». Після проведення дослідження ми виявили, що в експериментальні підгрупі благополучна сімейна ситуація визначається у рівнях, що поділяється на високий рівень, який підвищився на $27 \%$, середній - знизився на $17 \%$, низький - знизився на $10 \%$. У контрольній підгрупі високий рівень благополучної сімейної ситуації підвищився на $11 \%$, середній - знизився на $7 \%$, низький - знизився на 4\%. Рівень конфліктності: у експериментальні підгрупі високий рівень, який залишився незмінним, середній - знизився на $18 \%$, низький - підвищився на $18 \%$. У контрольній підгрупі високий рівень підвищився на $3 \%$, середній - знизився на $12 \%$, низький - підвищився на $9 \%$. На наш погляд, робота з агресивною дитиною має проводитися переважно у двох напрямах: пошук позитивних способів приборкання гніву; дорослим, які перебувають поряд з агресивною дитиною, необхідно пам'ятати, що виникненню й закріпленню у дітей агресивної поведінки сприяє особиста агресивність дорослих. На агресію ніколи не можна відповідати агресією, дорослий повинен вказати дитині приклад конструктивного розв'язання конфлікту. Говорячи про профілактику агресивної поведінки, можемо виділити специфічні (релаксаційні тренінги) та неспецифічні (не фіксувати увагу на небажаній поведінці дитини, реагувати і відгукуватися на будь-які позитивні зрушення у поведінці дитини) способи взаємодії здитиною.

Висновки та перспективи подальших досліджень. Після проведення експериментального дослідження ми дійшли висновку, що рівень агресивності учнів завищений, і тому можуть виникати конфліктні ситуації в спілкуванні з дорослими та однолітками. Важливу роль відіграє самооцінка психічних станів дитини, що проявляється у взаємовідносинах батьків та дітей. Безконфліктному спілкуванню батьків з дітьми сприяє підвищення педагогічної культури батьків, організація родини на колективних початках, підкріплення словесних вимог організацією виховання, інтересом батьків до внутрішнього світу дітей. Батьки повинні вчитися поважати унікальність, універсальність і недоторканність особи дитини, завжди прагнути розуміти дитину, увійти до іï образу мислення, вчитися розбиратися в мотивах вчинків дітей. Дозволяти дитині на практиці усвідомити свою поведінку або відчути результати своїх дій насправді. Перспективою майбутніх досліджень $\epsilon$ необхідність розробки комплексної тренінгової програми, спрямованої на корекцію неконструктивних стилів виховання в родині.

\section{Література}

1. Баришполь С. В. Посібник практичного психолога: психодіагностика, тестування, розробка уроків психологічного розвитку. Харків: Вид. група «Освіта», 2009. 267 с.

2. Вовк Г. Робота з агресивними дітьми. Психолог. 2009. № 44. С. 13-16.

3. Гулєвич Т. Знущання та агресія у школі. Психолог. 2010. № 40. С. 8-10.

4. Лоренц К. Агрессия (так называемое зло). Санкт-Петербург: АМФОРА, 2001. 348 с.

5. Ложкин В. Г., Повякель Н. И. Практическая психология конфликта. Київ: МАУП, 2002. 256 с.

6. Можгинский Ю. Б. Агрессивность детей и подростков: распознавание, лечение, профилактика. Москва: Когито-центр, 2008. 184 с.

7. Олифирович Н. И., Зинкевич-Куземкина Т. А., Валента Т. Ф. Психология семейных кризисов. СанктПетербург: из-во ЭКМОС, 2006. 360 с.

8. Хоменко Г. Агресивність підлітків: причини, профілактика, корекція. Психолог. 2009. № 35. С. 17-23.

9. Berkowitz L., Le Page A. Weapons as Aggression Existing Stimuls. Journal of Personality and Social Psychology. 1997. № 7. P. 133-138.

10. Feshbach S. Dinamies and Aggression. American Psychologist. 1997. № 17. P. 227-232. 